\title{
Semiotic and Dance: An Analysis of the Ballet Nazareth
}

\author{
Siane Paula de Araújo \\ Federal University of Minas Gerais, Belo Horizonte, Brazil
}

\begin{abstract}
This paper is a proposal of analyzing Grupo Corpo Dance Company's ballet Nazareth, on video. The work represents intersemiotic translation of the literature by Machado de Assis, as the stories Um Homem Célebre (A Famous Man) and Terpsícore (Terpsichore), to adapting to the music of Ernesto Nazareth by José Miguel Wisnik and therefore to the dance of Rodrigo Pederneiras, the choreographer. In this study, what is important is how the different languages, such as literature and music, are suitable for the dance's spectacle. Thereby, Peirce's semiotics, conceptions of translation of the Brazilian poet Haroldo de Campos and the concept of corpomídia ("bodymedia”) developed by teachers Helena Katz and Christine Greiner (Pontifícia Universidade Católica de São Paulo) are the main theoretical tools of analysis. Creating a legitimate form of contemporary dance, this proposal of ballet Nazareth's lecture begins about the first chapter's "rhizomatic" ramifications for the seven others transformed by excellence in Grupo Corpo’s choreographic language.
\end{abstract}

Keywords: semiotic, dance, Nazareth, Grupo Corpo

\section{Introduction}

This work seeks to analyze, from the semiotic bias, the Grupo Corpo Dance Company’s Nazareth ballet, on video. It is noteworthy that this spectacle was built by a translation process that involved different artistic codes, or languages, such as literature, music, and dance.

In the show, the work of the honored Ernesto Nazareth (1863-1934), a musician and composer of "Brazilian tangos”, is also adapted to the dance musician by José Miguel Wisnik (1948- ), songwriter and now teaches in the area of literature at the USP (University of São Paulo), which accomplishes this feat approaching writing music. Wisnik recreated the works of Ernesto Nazareth with also writer Carioca Brazilian Machado de Assis's (1839-1908) some literature references, which is highlighted in this paper the tales Um Homem Célebre (A Famous Man, 1883) and Terpsícore (Terpsichore, 1886) for the musical adaptation directed to the Grupo Corpo ballet.

The dance spectacle follows the same line of work when the choreographer of the group, Rodrigo Pederneiras, does a process of dance creation with links between the method of Wisnik composition—also based on Machado's writing — and the process of choreographic creating. Each choreography or music earns the title of the soundtrack intended. That is, each choreography or music presents entitlement "double”, or rather, having, for the most part, two nominations for each composition: one corresponding to the Wisnik adaptation and the other referring to the original music of Ernesto Nazareth. In the work, 10 titles in all organized into seven chapters which are proposed to examine the first chapter's "rhizomatic" ramifications for the seven others transformed in

Siane Paula de Araújo, professor, Ph. D. student, School of Fine Arts, Federal University of Minas Gerais. 
the Grupo Corpo’s choreographic language by excellence. Its first titles are matched by The Polka (musical adaptation of “Cross, Peril!”) and Waltz (on "Improvisation of Concert”).

In this case, agreeing with the words of Santaella (2002), when she says: “ . . the semiotic application calls for dialogue with more specific theories of processes of signs that are being examined” (the author's translation, p. VI). As soon as, beyond the Peirce's semiotics theoretical tool are used too for analyzing the dance archived on video the "creative transposition" concept by Campos (1970) and the corpomídia ${ }^{1}$ concept by Katz and Greiner (2005). Considering this fact, we also emphasize on this type of audiovisual production: a filmed dance occurred in the last time (in 1995). According to Valeska (2010), it appears in another genre that involves, by definition, a translation process between the linguistic codes of ballet and the film, concluding that dance video has a heterogeneous language, since its hybrid character.

\section{Irradiations of the First Caption: The Polka (“Cross, Peril!”)}

"Cross, Peril!" (1879) is an original "autodidact” track composed by Ernesto Nazareth when he was around his age of 15. A "Brazilian tango” was partitioned by José Miguel Wisnik in two different "motives”. Wisnik realized that when it comes to the first cell of the song with the left hand, you get one, similar to European music, such as polka, that is more marked with rhythm or more tonal genre. The second musical cell of the right hand resonates more the maxixe swing, that is the more atonal part of the musical rhythm with the African syncopation. In the words of the literary musician Wisnik (2008) this fact constitutes or gives the identity to own maxixe songs:

... Coexists the maxixe rhythm one motive batting in octaves in the right hand, in the second part, the melody, headless of the first sixteenth musical compass, values displacement the second and sixteenth syncopation and suggests the unmistakable usual's the maxixe. (Wisnik, 2008, p. 36, the author's translation)

This is an interesting way to engage with the corpomídia concept of this work, as well with the notion of "body" concerned. In other words, there is a "semiotic body" beyond the limits of flesh to be transfigured into a signic tub related senses. Within this idea of "body" is appropriated corpomidia idea on the reciprocal traffic movement of the information in flow "inside and outside" of this body which transforms through a process of change, or evolutional, as more properly the corpomídia concept is referred to, and how also gives the quote below:

There is no one so fit to be demonstrated as a means for evolution to occur. (...) Body is medium, nothing more than a temporary result of agreements whose history goes back a few million years. There is a continuous flow of information being processed by the environment and the bodies that are in it. Thus, the processing becomes a prerequisite. (Katz, 2003, p. 263, the author's translation)

All this movement of meanings can also be seen in the way the musician Wisnik composed the score for the ballet Nazareth, that is specifically about the beginning of the first chapter generating the "musical motives" translated to the dance by choreographer Rodrigo Pederneiras. In this process, a game of opposite senses or "tensions" can be observed between many elements such as: polka/the maxixe; tap the right hand/left hand; the maxixe swing/classic technique ballet and so on. These opposites' relations introduce the "mirrored senses" metaphor in this analysis. In this case, the mirror means not projection of an inverted image, but, mainly,

\footnotetext{
${ }^{1}$ The term means "bodymedia” written by teachers of the Pontifícia Universidade Católica de São Paulo.
} 
associated senses that form an "all” integrated in the audiovisual artistic work.

This same idea also gets a contextual relationship with Machado's tale, the contemporary music of Ernesto Nazareth, Um Homem Célebre (A Famous Man). In this tale, the main character, “Pestana”, is a musician and celebrated, or "famous" for his compositions of polka, a rhythm originating from Bohemia to spread across Europe, but becoming more typical of Brazilian lascivious life, or, as in the tale, also present in Rio de Janeiro soirees of the late 19th century, as can be seen in the following quote:

Came of the piano wiping his brow with his handkerchief. And would go to the window, when the girl stopped him. There was dancing, just an intimate soiree, few people, twenty people in all who had gone to dinner with the widow Camargo, Areal Street, that day of her birthday, November 05, 1875 ... Good and plump widow! She loved laughter and plays (...). With the soul and diligence got him there a few dances (...), the widow requested a homage to the Pestana very particular: I want that us touch now that his polka Não Bula Comigo, Nhonhô! ("Not Me Bullying, Nhonhô!”). (Assis, 2007, p. 417, the author's translation)

However, the musician dreamed of being recognized as a composer of classical music, or to compose music close to their icons idols who he considered high European strain, as Mozart. Outraged in just getting composed polkas, the personage finds himself immersed in that creative crisis, revealing his existential problem generated by an against point that occurs in a constant game of antithesis and synthesis.

Thus, it is seen that the relations of synthesis and antithesis are greatly present in Machado tale, like in ballet Nazareth. At this time, relations of meaning are noticed as regards the concept of "creative transposition" by Campos (1970). This can be observed about translation of the literary universe to the dance when checked the costumes in on the scene. It is observed signic contrasts between the costumes colors in black and white. In other words, the ballerina's colors costume in "black and white" form a synthesis and antithesis of meanings iconicity and indexicality, as is conferred in Figure 1:

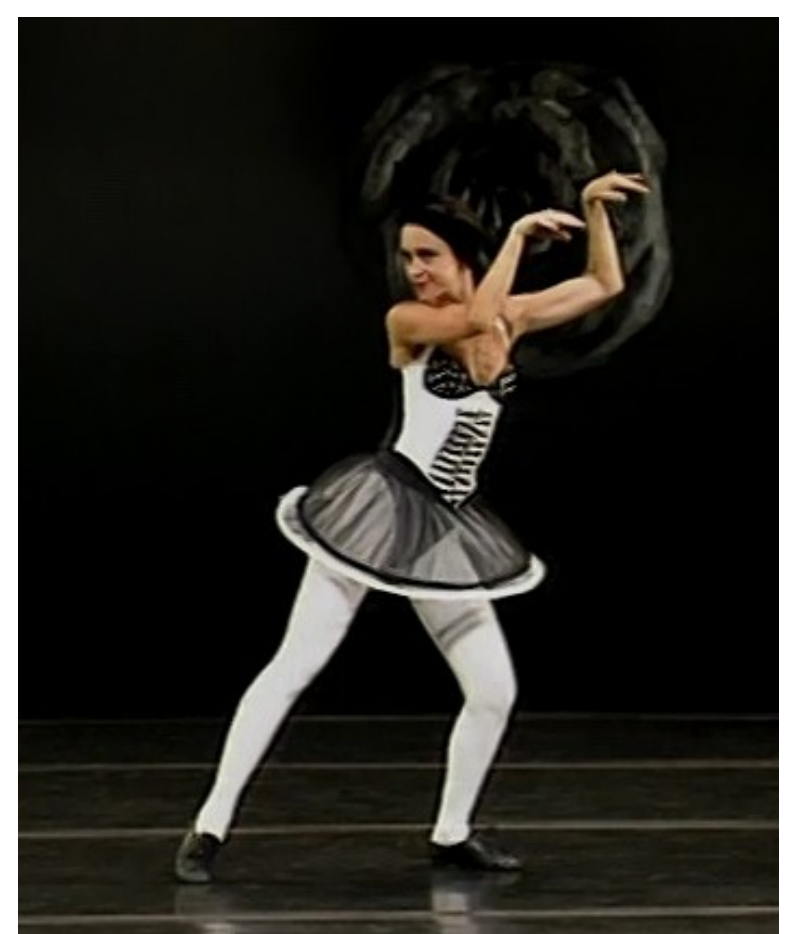

Figure 1. The contrast of colors in the costumes of the dancer. Source: Adapted from Corpo, 1995, DVD Nazareth, 10'26". 
The ballerina's colors costume in "black and white" can represent in iconic and indexical semiotic aspect the colors of the piano key, and the Ernesto Nazareth pianist or personages of Machado de Assis literature as Pestana. This colors signs can arouse, for example, a fruition of the ballet music. The same way when referring to the ballerina's moves can develop sense relations with the instrument "piano" too. It is not only as meaning existential, but as cultural convention from a historical symbolic relationship of the Brazil. The piano was a musical instrument very present in the Brazilian culture of the 19th century and an element of modernization representation that the country lived in eras of post-abolitionism of slavery. About this fact Wisnik (2008) portrayed:

The astonishing fact is then the piano to replace, in part, as a commodity fetish, a slave how own merchandise, putting yourself in the place of this as if denied at the same time promoting the relocation of the transit of capital, contributing to connect them to the early centers. (p. 66, the author's translation)

Just as the "piano" is also a "key" of the story itself Um Homem Célebre (A Famous Man) instrument, besides other works Machado as in the tale "Trio in La minor" and the novel "Jacob and Esau", these works also permeate the construction of spectacle analyzed. It is also important to detach the honored renowned Brazilian pianist Ernesto Nazareth in the ballet whose personal identity is not separated of his working tool: the piano.

Other evidence also emphasizes the idea spelled out by the semiotic potential of the costume is in "tension" relationship between the lines drawn by the movements of the body of the dancer and the ways that lead to "reflect" when at the same time has a connexion between how their movements are conducted. These movements seem to merge the earnest craft of a pianist, but also bring a sense of joy and casualness for the dancer's body over the pulsed stimuli in the musical pace.

As soon, to the rhythm of "trans-creation" kinetic literature-music-dance has a signic indexical relation on the first choreography of the ballet Nazareth. In this dance one ballerina doing moves with yours wrists and fingers in frequent breaks that may refer a person playing the piano.

The ballerina dances a solo for two musical phrases, and this fact also increases the solar indexical semiotic dimension related to the fact playing the piano. It is noteworthy also that the pianist takes an individualistic profession, marked only by dialogue established between the musician and his instrument work. As well as, quali-iconic signs of the Peirce's semiotics are observed as the dancer to isolate themselves in a scene composed just for her. In this moment of the ballet, there is not definition of the lighting. It is initially demarcated only on ballerina's body and blackout in other spaces onstage. This fact also intends to show the figure of pianist who will be portrayed throughout the ballet.

In addition, the piano itself is an instrument from Italian origin. In this way brought to Brazil with it a range of values considered noble to society of the time since the early 20th century, according to Wisnik (2008): "Piano brings a prestigious piece of Europe (...)" (p. 42, the author's translation). Furthermore, the piano simbolic was transformed by the dynamics of folkways observing an interweaving of the musical repertoire of ballroom and of concert.

In ballet Nazareth this issue is contained by the constitution of mixed choreography language of Grupo Corpo through the process of hybridization between different genres of dance evoking simultaneously the popular dance and classical ballet. These different genres of the dance were transformed by Rodrigo Pederneiras 
choreographer in a third genre: the contemporary dance. He recreated the maxixe dance through the syncopation of the musical swing, but using the ballet technique. In other words, similar the music process, the choreographer merges the ballroom dances—-like the maxixe — and dances of concert—as ballet. This hybrid movement is underpinned by cultural antithesis generated in between these extremes genres of dance-ballroom and concert- that come together to make this work, generating a next set of mirrors.

On a more intrinsic look at the scene, this first chapter of the show, while the dancer performs at the beginning of the choreography intermittent little hops and hip movements, as quavers, own the maxixe type nod, also makes frequent external rotation of the right foot in back bending and flexing knees, typical of traditional samba. At the same time, the ballerinas accomplishes movements exuding body lanky lines, constant gyrations, hops, port de bras (arms' movements of the ballet) and others classical ballet steps, as well as unique and original combinations of movements with arms and legs: a fully contemporary dance.

It is realized, however, different sign systems being intersected at the same time in the choreography for the creation of choreographic Grupo Corpo's language emphasizing again the hybrid aspect in terms of gestural meaning that making present (It is indexically) the distinct artistic movements and different body codes, such as samba, the maxixe, and classical ballet.

Then one realizes clearly a relationship between the senses mirrored literature, music, sets and costumes through a network of signs creating mirrored reflections senses. In this context, or "environment”, the logic of the concept of communicative corpomídia praises instance in dialogic relation, that is, with the "other" (in plural), since the perceived direction of motion of the body of the dancer that makes up the process discursive scene.

Therefore, the outstanding evidence generated in this first title of the first chapter of the series is the antithesis and synthesis senses in a situation of opposites that unifies. And this situation is irradiated by the other seven chapters of the spectacle.

There is also evident lecture which these signic relationships marked by synthesis and antithesis "reflecting" the transit of events in changes or transformations present in Grupo Corpo's dance meets also the carnivalization's aesthetics as proposed by Bakhtin (1997) in Problems of Dostoevsky's Poetics:

The carnivalesque thinking is also present in the field of the latest issues, not showing for these, however, clear abstract or dogmatic religious-philosophical solution, but interpreting them in concrete—sensory form of shares and carnival images. Therefore, carnivalization allowed by carnival worldview, download the latest issues of abstract philosophical level to the concrete level of sensory images and events, carnivalistic dynamic, diverse and alive. (p. 115, the author's translation)

Exemplifies this relationship the categories carnivalization, as it is called by the author, when it prioritizes the ambivalent nature of the carnivalesque images that "encompass the two fields of change and crisis" (Bakhtin, 1997, p. 108, the author's translation). This can be observed and related to the choreographic aspects in this ballet, i.e., "the peer files, selected in accordance with the contrast (high-low, full-empty, etc.) and similarity (doubles-twins)": the elements of category carnivalization also present at the dance. This presents the relationship within the overall context of the work generated by the representation of the senses in the synthesis and antithesis, marketed as a game of mirrors, as already said. 


\section{Specification of the Title Waltz (“Improvisation of Concert”)}

In this title, a specificity is the dance of the ballerina that is similar a "goat mix and the Swan” as said Wisnik in Nazareth DVD. Agreement with the same correspondence, Terpsícore (Terpsichore), Machado’s story, forward character dance of Glória, seems as quoted: "From the Street Porfirio satyrs dug his eyes, followed in his agile, elegant and sensual movements, mixing goat and swan” (Assis, 2007, p. 402, the author’s translation). This dance does a movement with the music which reflected in a trend towards slower movements in faster time music, and the opposite occurs, when it tends to make quick movements in a more slow soundtrack.

These elements also shoot at the level of semiotic iconicity, a sense of "sublime” about the transitions between the titles The Polka and Waltz, as the latter title begins almost imperceptible, because there is no short musical break and not interrupting the preceding scene, only prolongs. The parties really make a whole, but are slow musical tempo by previous brief interruption.

Thus, observing the transition and the sequence between The Polka and Waltz titles, perceives a constant “return” of events, actions and the intentions of gestures, repetitions of movements, and choreographic drawings. An example is how choreographer Rodrigo Pederneiras uses the dancers' body with the many turns, twists and shifts according to their periphery of the body maintaining the fixed centre. In the same way, there are similar situations in this work which can also configure the poetic body created by the corpomídia concept as proposed by Katz and Greiner (2005). In this sense, this concept is presented as an idea to support the understanding of choreographic movements with regard the aesthetics of the constant "return”. This is possible because that concept also refers to the sense of "mirrored relationships", or dialogical relations between one and others (in plural) in this work.

As soon as the semiotic movement in this context is provided by the flow of the senses that occurs through the "fusion" of events in movement. This is the condition of a constant "return" that leads to another sense and transforming the meaning of a same sign. This provided mobility for some scenic reason or viewpoint, on the same idea of the representation of mirror aesthetics forming senses in spiral, i.e., forming "mirrors spiral” as the category of carnivalization by Bakhtin (1997) also provides.

In this sense, the "mirrors spiral” reflects on the reading to give importance to what is mediating, or rather the interface dialogical relationship between two or more "bodies" or "signs" that communicate. The relations of meaning occur now not only in opposition, but in "double mirroring” marked by the presence of a single sign that is repeated, nevertheless with different meaning, transformed. Then, that forms a constant "return", or "mirrors spiral” it tends to infinity of meanings. Thus, “white and black” or "black and white” to read what matters is the "and", or rather, the linking the two together on the same level of significance of the ballet Nazareth.

Although these senses mirrors spiral radiate throughout the work, this second title of the first chapter ends by cutting video editing. This occurs when the screen covers the entire framework in which men and women dancing together for a continuous swing of the hips and arms. At the same time, there is to the approximation of the camera until the scene closes to focus on a single image that is considered the allegory of the musical genre maxixe and allegory of romance: “a rose” of the scenery. This scene emphasizes “mirrored” or dialogical relationship between choreography, costumes, music, and scenery as put in this work. Moreover, not represents an end, but the direction for a continuum. 


\section{Conclusions}

At any rate, this proposal analysis shown by the characters of the Nazareth's first chapter has reflected in all spectacle. Furthermore, the "mirrors in opposite, in duplicate or spiral" observed still reflecting in the trial of this ballet as a contemporary legitimate form of dance. This shape a continuum of meanings reflected throughout the dance and translates itself the Grupo Corpo’s choreographic language.

In this context, the "body" by issuing virtual dance on video is taken as a sign or as a semiotic body, possessing the iconic, indexical, and symbolic instances in the space of representation. This "space" is the relationship between the "organic body" of the dancer with the "other" in the plural, i.e., with scenario, costumes, lighting, music, and more.

So polyphony or dialogical relationship of "I" with the "other" (plural), which is the dimension of communication shows that the semiosis of meaning happens to the endless possibilities of reading in a "body" that is allowed to penetrate the screen, then develop spatiotemporal evidence of signs in an audiovisual dimension.

\section{References}

Assis, M. (2007). 50 contos de Machado de Assis (50 tales of Machado de Assis) (pp. 401-425). São Paulo: Letters’ Company (Companhia das Letras).

Bakhtin, M. (1997). Problemas da poética de dostoiévski (Problems of Dostoevsky’s poetics). Rio de Janeiro: University Forensic (Forense Universitária).

Campos, H. (1970). Metalinguagem e outras metas (Metalanguage and other aims). Petropolis: Our Time (Nosso Tempo).

Corpo, C. D. G. (1995). Nazareth [Video DVD]. BH: Invideo (Envideo).

Katz, H. (2003). A dança, pensamento do corpo (The dance, body thought). In A. Novaes (Ed.), O homem-máquina: A ciência manipula o corpo (The man-machine: Science manipulates the body) (pp. 261-274). São Paulo: Letters' Company (Companhia das Letras).

Katz, H., \& Greiner, C. (2005). Por uma teoria do corpomidia ou a questão epistemológica do corpo (For a theory of corpomidia or the epistemological question of the body). Archivo Virtual de Artes Escénicas (Cuenca-UCLM: Virtual archive of performing arts). Retrieved from: http://artesescenicas.uclm.es/archivos_subidos/textos/237

Peirce, C. S. (2008). Semiótica (Semiotics). São Paulo: Perspective (Perspectiva).

Santaella, L. S. (2002). Semiótica Aplicada (Applied semiotics). São Paulo: Thomson.

Wisnik, J. M. (2008). Machado maxixe: O caso pestana (The Maxixe Machado: The Pestana case). São Paulo: Publisheet (Publifolha). 